\section{Click It or Ticket Campaign — May 22-June 4, 2017}

In 2015, a total of 22,441 passenger vehicle occupants died in motor vehicle crashes in the United States, representing a $6.6 \%$ increase from 2014. Among those who died, $48 \%$ were unrestrained by a seat belt (or an age- and size-appropriate car seat or booster seat for younger children) at the time of the crash, whereas only $14 \%$ of 38,152 passenger vehicle occupants who survived a crash where at least one person died were unrestrained (1). Using a seat belt is one of the most effective ways to prevent serious injury or death among older children, teens, and adults in the event of a crash (2). Despite the effectiveness of seat belts, millions of persons in the United States continue to travel unrestrained (3).

Click It or Ticket is a national campaign coordinated annually by the National Highway Traffic Safety Administration (NHTSA) to increase proper use of seat belts through safety education and strong law enforcement. Click It or Ticket takes place from May 22 to June 4, 2017. Law enforcement agencies across the nation will conduct intensive, high-visibility enforcement of seat belt laws, which has been demonstrated to be effective in increasing seat belt use (4). Enforcement is particularly encouraged from 6 p.m. until 5:59 a.m., because seat belt use is lower at night (1). Additional information and publication materials for the 2017 Click It or Ticket campaign are available from the NHTSA website at https://www.trafficsafetymarketing.gov/get-materials/seat-belts/click-it-or-ticket.

State-specific fact sheets on seat belt use, strategies to increase restraint use, and costs of crash deaths are available from CDC at https://www.cdc.gov/motorvehiclesafety/seatbelts/states. html and https://www.cdc.gov/motorvehiclesafety/statecosts/ index.html. Additional information on preventing motor vehicle crash related injuries is available from CDC at https:// www.cdc.gov/motorvehiclesafety.

\section{References}

1. National Center for Statistics and Analysis. Motor vehicle crashes: overview. Report no. DOT HS 812 318). Washington, DC: National Highway Traffic Safety Administration, National Center for Statistics and Analysis; 2015. https://crashstats.nhtsa.dot.gov/Api/Public/ ViewPublication/812318

2. Kahane CJ. Fatality reduction by safety belts for front-seat occupants of cars and light trucks updated and expanded estimates based on 1986-99 FARS data. Report no. DOT HS 809 199. Washington, DC: National Highway Traffic Safety Administration; 2000. https://crashstats.nhtsa. dot.gov/Api/Public/ViewPublication/809199
3. Shults RA, Beck LF. Self-reported seatbelt use, United States, 2002-2010: does prevalence vary by state and type of seatbelt law? J Safety Res 2012;43:417-20. https://doi.org/10.1016/j.jsr.2012.10.010

4. Dinh-Zarr TB, Sleet DA, Shults RA, et al.; Task Force on Community Preventive Services. Reviews of evidence regarding interventions to increase the use of safety belts. Am J Prev Med 2001;21(Suppl):48-65. https://doi.org/10.1016/S0749-3797(01)00378-6

\section{World IBD Day — May 19, 2017}

World IBD Day is recognized on May 19 to raise awareness of inflammatory bowel disease (IBD) and the two conditions that comprise it: Crohn's disease and ulcerative colitis, both of which cause chronic inflammation of the gastrointestinal tract. World IBD Day is sponsored by the European Federation of Crohn's and Ulcerative Colitis Associations, which includes the Crohn's \& Colitis Foundation.

In 2015, approximately 3 million adults in the United States self-reported having a diagnosis of IBD, representing a large increase from <2 million in 1999 (1,2). Symptoms can include frequent diarrhea, abdominal pain, and bloody stools, as well as fever, weight loss, fatigue, and night sweats. The cause of IBD is not known, but genetic susceptibilities, problems with the immune system, and environmental exposures, such as smoking and certain microorganisms, all might play a role. Although to date, IBD cannot be prevented, there are ways to manage the symptoms and prevent complications. Additional information is available at https://www.cdc.gov/ibd/. Additional information on World IBD Day is available from the Crohn's \& Colitis Foundation (http://www.crohnscolitisfoundation. org/WorldIBDDay/).

\section{References}

1. Dahlhamer JM, Zammitti EP, Ward BW, Wheaton AG, Croft JB. Prevalence of inflammatory bowel disease among adults aged $\geq 18$ yearsUnited States, 2015. MMWR Morb Mortal Wkly Rep 2016;65:1166-9 https://doi.org/10.15585/mmwr.mm6542a3

2. Nguyen GC, Chong CA, Chong RY. National estimates of the burden of inflammatory bowel disease among racial and ethnic groups in the United States. J Crohn's Colitis 2014;8:288-95. https://doi.org/10.1016/j. crohns.2013.09.001 